\title{
Occurrence of Listeria monocytogenes in cheese and ice cream produced in the State of Paraná, Brazil
}

\author{
Wanda Moscalewski Abrahão1, Paulo Roberto da Silva Abrahão², Cristina Leise Bastos Monteiro², \\ Roberto Pontarolo ${ }^{1 *}$
}

${ }^{1}$ Departamento de Farmácia, Setor de Ciências da Saúde, Universidade Federal do Paraná, 2 Departamento de Patologia Básica, Setor de Ciências Biológicas, Universidade Federal do Paraná

*Correspondence:

R. Pontarolo

Departamento de Farmácia do Setor de Ciências da Saúde

Laboratório de Controle de Qualidade e Química Farmacêutica

Universidade Federal do Paraná

Avenida Prefeito Lothario Meissner,

632, Jardim Botânico

80210-170 - Curitiba - PR, Brasil

E-mail: pontarolo@ufpr.br
The occurrence of Listeria monocytogenes in Brazilian ice cream and in some soft and semi-soft cheeses produced and sold in the State of Paraná, Brazil was evaluated. Ninety samples of cheese and sixty samples of ice creams were analyzed following the guidelines outlined by the official institutes, AOAC and FDA. In the ice cream samples no isolation of Listeria spp. was found. The percentage of these ninety samples of cheeses positive for Listeria spp. was $12.20 \%$. Listeria monocytogenes was detected in six (6.70\%) of the same samples. The presence of Listeria innocua was five (5.50\%) in the samples analyzed was also observed. According to the results of the work it is possible to presume that there is a potential health risk to the brazilian population, heightened by aging and the increase in immunodepressed. These results indicate the need for the implementation of monitoring of these microorganisms as much by producers as by health inspectors. The results also show that the VIP (visual immunoprecipitation assay) is a viable triage method of contaminated samples for the liberation of products for commercialization, as it is quick, reliable and does not require additional equipment other than that normally found in production labs, while presenting reliable results.

\section{INTRODUCTION}

Microorganisms of the genus Listeria are widely distributed in nature, although with a limited number of species of medical and veterinary significance (Schuchat et al., 1991; Low, Donachie, 1997; McLauchlin, 1997).

Many studies cite food products, especially cheeses and other milk based products as the principal sources of Listeria monocytogenes transmission (Ho et al., 1986; Azadian et al., 1989; Ryser, Marth, 1990).

The incidence of Listeria monocytogenes in soft and semi-soft cheese varied from $0.50 \%$ to $46.00 \%$ (Terplan et al., 1986; Farber et al., 1987; Beckers et al.,1987; Weber et al., 1988; Pini, Gilbert, 1988; Rorvik, Yndestad, 1991; 
Cordano, Rocourt, 2001; Guerra et al., 2001; Manfreda et al., 2005; Pintado et al., 2005; Colak et al., 2007). Studies related to the occurrence of Listeria monocytogenes in cheeses produced in Brazil have shown contamination of $1.40 \%$ to $41.17 \%$. (Destro, 1991; Oliveira, 1993; Schwab, 1994; Silva et al.,1998; Souza, 2002; Borges et al., 2003; Branco et al., 2003; Ramos, Costa 2003).

Data provided by the Brazilian Association of the Cheese Industry - ABIQ, indicate that Brazilian production in 2005 was around 510,000 tons of cheese. The types of cheese with the highest consumption include mozzarella, table, Brazilian Minas, soft cream cheese and cream cheese for culinary purposes. The production of cheese is concentrated, mainly, in small and medium sized industries, in the South and Southeastern regions of Brazil.

Resolution number 12 of January $2^{\text {nd }}, 2001$ (Brasil, 2001) establishes the microbiological standards for foods intended for human consumption and defines the search for Listeria monocytogenes (absence or presence in $25 \mathrm{~g}$ ) only in the cheese sub-group, specifically those which present medium, high and very high humidity.

Ice cream, despite its frozen storage, is also a very good medium for microbial development, thanks to its high nutritional level, its nearly neutral $\mathrm{pH}$ (6-7) and to its long period of storage. In 2001, the Brazilian National Health Vigilance Agency -ANVISA monitored 863 samples of frozen food, and detected $23.00 \%$ which were in disagreement with the microbiological standards (Brasil, 2002).

Windrantz and Arias (2000) performed a bacteriological evaluation of ice cream from San Jose, Costa Rica, and obtained a $12.30 \%$ occurrence of Listeria monocytogenes. All the isolates were obtained from homemade ice cream samples.

Despite the risk of L. monocytogenes in dairy products, there are few studies about its incidence in cheese and ice cream produced in Paraná, Brazil.

The aim of this work was to determine the occurrence of Listeria monocytogenes in different kinds of cheese and ice cream produced in the State of Paraná, Brazil using the quick VIP(visual immunoprecipitation assay) Biocontrol in the sample triage.

\section{MATERIAL AND METHODS}

During 2001 and 2002, ninety samples from different kinds of cheese were collected in establishments selling food in a number of 16 regions of the State of Parana (Apucarana, Cascavel, Cianorte, Cornelio Procopio, Curitiba, Foz do Iguaçu, Francisco Beltrão, Guarapuava, Irati, Ivaipora, Londrina, Maringa, Paranavai, Pato Branco, Toledo and Umuarama); and in 2004, sixty samples of ice cream were collected in small companies of frozen foods in the Curitiba area. All samples of collected cheeses were produced in this State and were classified according to the Brazilian Cheese Industry Association criteria as: mozzarella (19), table (6), cream cheese (1); fresh cheeses subdivided into, Brazilian Minas (25) and ricotta (11); handcrafted cheese, subdivided into: colonial (23), mountain (2), standard Minas (1), gouda (1) and provolone (1). The samples were packed in first use plastic bags, tagged and kept refrigerated during the transportation to the laboratory, and then analyzed immediately. The humidity of the cheese samples was determined in a vacuum stove. The humidity content of the cheeses was classified as follows: low humidity cheese, when the humidity content was lower than $36.00 \%$, medium humidity cheese, when the humidity content was between 36.00 and $46.00 \%$, high humidity cheese, when the humidity content was between 46.00 and $55.00 \%$, and very high humidity cheese when the humidity content was higher than $55.00 \%$ (Brasil, 2001).

The detection of Listeria monocytogenes and related Listeria spp was performed using the rapid visual immunoprecipitation assay (VIP) / AOAC 997.03 method as a screening technique. This method uses a proprietary reagent system to form an antigen-antibody-chromogen complex if Listeria is present. Appropriately enriched samples are added to the VIP unit; any Listeria antigens will bind to the antibody-chromogen complex as it flows across a supporting membrane. When Listeria is present, the antigenantibody-chromogen complex will form a detection line in the test sample window. Sample flow will continue down the membrane to form a control line in the test verification window regardless of whether the sample contains Listeria (Warburton, Boville 2003).

Aliquots of $25 \mathrm{~g}$ of products were homogenized with $225 \mathrm{~mL}$ of modified Fraser broth with lithium chloride 8M for 30 seconds in a "stomacher" and were incubated at $30^{\circ} \mathrm{C}$ for 28 hours. After the incubation period, the flask with the primary selective enrichment was slightly agitated. Then $1 \mathrm{~mL}$ of the homogenized sample was transferred to a test tube with $9 \mathrm{~mL}$ of enrichment broth of Listeria buffered (BLED) which was incubated at $30^{\circ} \mathrm{C}$ for 24 hours (secondary selective enrichment). Then, $1 \mathrm{~mL}$ of the BLED broth was transferred to a sterile test tube and heated in a water bath at $100^{\circ} \mathrm{C}$, for 5 minutes. An aliquot of $0.2 \mathrm{~mL}$ of BLED broth previously heated and cooled, at room temperature, was transferred for inoculation in the VIP ${ }^{\mathrm{R}}$ Biocontrol device in the specific area with round shape. After 10 minutes, the readout was performed (BioControl Systems, 1997).

The positive BLED broths in the VIP ${ }^{\mathrm{R}}$ Biocontrol test, which were not previously heated, were plated on three se- 
lective media according to the Food and Drug Administration (FDA, 1995): (a) selective phenylethane moxalactam lithium chloride agar for Listeria spp. and supplemented with esculin $1 \mathrm{~g} / \mathrm{L}$, ferric ammonium citrate $0.5 \mathrm{~g} / \mathrm{L}$ (modified LPM), (b) selective Oxford Agar for modified Listeria spp. (MOX; Oxford Agar base; Merck) supplemented with moxalactam $(15 \mathrm{mg} / \mathrm{L})$ (Sigma) and colistine sulfate $(10 \mathrm{mg} /$ L), and (c) Agar Palcam (PAL; Merck) supplemented with polymyxin $\mathrm{B}(10 \mathrm{mg} / \mathrm{L})$, acriflavine $(5 \mathrm{mg} / \mathrm{L})$, and ceftazidime (20 mg/L) (FDA, 1995).

The Palcam and Oxford agar plates were incubated at $35^{\circ} \mathrm{C}$ for $48 \mathrm{~h}$ and the LPM agar at $30^{\circ} \mathrm{C}$ for $48 \mathrm{~h}$. In the cases of presumptive colony growth, five typical colonies were selected and then purified in tripticase soy agar supplemented with $0.60 \%$ of yeast extract and identification tests at genus level were performed: (a) umbrella-like growth in semi-solid sulfite-indol-motility medium with addition of $0.05 \%$ of TTC (triphenyltetrazolium chloride) at $25^{\circ} \mathrm{C}$; (b) catalase production; (c) acid production from glucose, lactose and saccharose in agar triple sugar iron (TSI); (d) methyl red test reaction; (e) Voges-Proskauer test and (f) bile-esculin test. The biochemical assays at species level involved: (a) nitrate reduction; (b) hemolysis production in blood agar with Columbia base supplemented with $5.00 \%$ of sheep blood; (c) fermentation of xylose, ramnose, and manitol in basic medium of bromocresol purple; (d) synergistic hemolysis test in the CAMP factor (Christie-Atkins-Munch-Peterson test) in sheep blood agar. A rapid serum agglutination test with somatic homologous antiserum was carried out with the pure cultures previously grown in nutrient agar at $30^{\circ} \mathrm{C}$ for a period of $18-24$ hours. (FDA, 1995)

The isolates identified as Listeria spp., were submitted for complementary biochemical characterization in the Adolfo Lutz Institute (SP). The serological characterization was made in the Oswaldo Cruz Institute.

The negative results in VIP assays were accepted as absence of Listeria spp in $25 \mathrm{~g}$ of samples.

The presence or absence of $L$. monocytogenes in 25 $\mathrm{g}$ of food was the criterion used to classify the analysed food articles as appropriate or inappropriate for consumption.

Results were analyzed with $\mathrm{Z}$ test for two proportions using the Microsoft Excel. Ap $\leq 0.05$ was considered statistically significant.

\section{RESULTS AND DISCUSSION}

From a total of 90 samples of different kinds of cheese, $11(12.20 \%)$ were positive for Listeria sp, subdivided as $L$. monocytogenes in six samples $(6.70 \%), L$. innocua in five samples (5.50\%). From a total of 60 samples of ice cream analyzed, none were positive for Listeria spp. The serovar distribution analysis showed that $100 \%$ of the L. innocua isolates belonged to serotype 6 a and for three of the Listeria monocytogenes isolates tested, serovar prevalence was $1 / 2 \mathrm{a}$.

Eleven samples of cheese showed positive evidence of VIP ${ }^{\mathrm{R}}$ Biocontrol for Listeria sp. Positivity was determined through the observation of a gray line in the result hole of the device, indicating the presence of flagellate antigens of Listeria spp., as well as the appearance of a gray line in the control hole indicating the correct operation of the device in the readout times of 10 and 20 minutes, respectively.

After selecting five suspect colonies in the selective media for Listeria spp. (modified LPM, Oxford agar and Palcam agar) from the 11 BLED broths with positive VIP ${ }^{R}$ proof, biochemical identification at genus and species level was performed. In the identification proof, all isolates presented positive results for the genus Listeria (catalase, motility in umbrella shape, bile esculin test, production of acid from glucose, lactose and saccharose in TSI agar) differing from the sugar fermentation profile, $b$-hemolysis and CAMP tests for $S$. aureus. All the strains identified as L. monocytogenes produced b-hemolysin and were positive for the CAMP tests, reduction of nitrate to nitrite and fermentation of xylose and manitol in basic medium of bromocresol purple.

The cheeses were classified as low humidity (13), medium humidity (33), high humidity (20) and very high humidity (24). The samples of very high humidity content (26.70\%), presented the highest occurrences of Listeria spp. (25.00\%) and Listeria monocytogenes (12.50\%). In medium and high humidity cheeses, the Listeria spp contamination was $12.12 \%$ and $5.00 \%$ respectively. Listeria monocytogenes was not isolated in high humidity cheeses but in medium humidity samples was $9.09 \%$. Listeria spp. was not isolated using this methodology in cheeses with a low humidity content. These results are shown in Figure 1.

Table I and II show the results of statistical analysis looking for any difference determined by the contamination

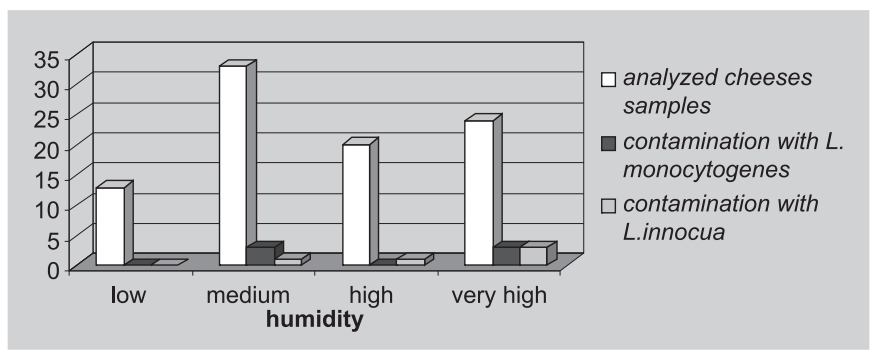

FIGURE 1 - Humidity content of cheeses and contamination level with Listeria monocytogenes and Listeria innocua 
degree as function either from the moisture content or from Listeria species. No statistical significance $(\mathrm{p}>0.05)$ was found.

TABLE I - Occurrence of Listeria spp. in cheese

\begin{tabular}{lcc}
\hline & \multicolumn{2}{c}{ Listeria spp. } \\
Results & L. monocytogenes & L. innocua \\
\hline $\mathrm{f}$ & 6 & 5 \\
$\mathrm{f}(\%)$ & 54.50 & 45.40 \\
$\mathrm{Z}$ & 0.303 & \\
$\mathrm{p}$ & 0.762 & \\
\hline
\end{tabular}

$\mathrm{f}$ - frequency; $\mathrm{f}(\%)$ frequency $(\%) ; \mathrm{Z}-\mathrm{Z}$ test for two proportions from one group with mutually exclusive group

TABLE II - Occurrence of Listeria spp. in cheese as a function of humidity

\begin{tabular}{lcc}
\hline & \multicolumn{2}{c}{ Humidity } \\
Results & Medium & Very high \\
\hline $\mathrm{f}$ & $4(33)$ & $6(24)$ \\
$\mathrm{f}(\%)$ & 12.10 & 25.00 \\
$\mathrm{Z}$ & -1.262 & \\
$\mathrm{p}$ & 0,207 & \\
\hline
\end{tabular}

$\mathrm{f}$ - frequency; $\mathrm{f}(\%)$ frequency $(\%) ; \mathrm{Z}-\mathrm{Z}$ test for two proportions from independent groups

Traditional methods for the detection of $L$. monocytogenes in food are based on the use of a specific culture medium for the enrichment and isolation of possible existing microorganisms, followed by biochemical confirmative and serological assays. The greatest disadvantage of the traditional methodologies used to isolate $L$. monocytogenes, is the time necessary to obtain the results. The procedures of enrichment, isolation and biochemical assays, required for the confirmation of the isolated strains, can take two weeks or longer. So, methods are being developed to produce faster and more reliable results and to improve laboratory productivity. Considering that the majority of the products analyzed presented a short "sell by date" period, time spent waiting for the results could compromise product commercialization. Thus, realization of analysis through a faster method was sought. The VIP method was chosen due to the ease in obtaining this reagent system and because it did not require the acquisition of equipment not already available in microbiology laboratories. Screening by the VIP method economizes time, materials and man power. The conventional method will be used only when samples prove positive for Listeria spp. VIP screening method makes detection and identification faster, more convenient, more sensitive, with greater specificity and improves the laboratory productivity. The presence of L. monocytogenes in $25 \mathrm{~g}$ aliquot classifies these products as inappropriate for consumption in accordance with the Brazilian law (Brasil, 2001) which stipulates the absence of $L$. monocytogenes for cheeses with medium, high and very high humidity contents. Quantification of the pathogen is not required by current Brazilian legislation.

Souza (2002) detected $1.40 \%$ of $L$. monocytogenes in 70 samples of hand-made sour cheese sold in Fortaleza - CE, while Ramos and Costa (2003) detected $1.70 \%$ in samples of the same kind of cheese sold in Manaus.

Oliveira (1993) detected $2.00 \%$ of Listeria monocytogenes in Brazilian Minas cheese in the retail business of Goiânia - Goiás. This percentage was also found by Schwab, in 1994, in colonial hand-made cheese samples sold in Porto Alegre. Destro (1991) isolated $L$. monocytogenes in $10.00 \%$ of Brazilian Minas cheese samples, while Silva et al. (1998) found a higher incidence $(41.20 \%)$ of L. monocytogenes in hand-made Brazilian Minas cheese. However, other authors like Casarotti et al. (1994) and Feitosa et al. (2003) did not detect this microorganism in samples of Brazilian Minas cheese, sold in Piracicaba, São Paulo, nor in sour cheese and butter produced in the State of Rio Grande do Norte, respectively. Silva et al. (2003) collected 218 samples of cheese along the production line and the environment in two factories of Minas Frescal cheese. Thirteen isolates of Listeria spp. were found in these samples, of which $70.00 \%$ were positive for L. innocua and $15.00 \%$ for L. monocytogenes.

When evaluating the existing research in relation to the occurrence of Listeria monocytogenes, a comparative study between them is difficult due to the range of analytical methods used, as well as differences in culture medium, sampling patterns adopted in each case and in the results achieved, which may have resulted in different detection levels. Further, according to Wong et al. (1990), differences in occurrence data can also be explained by the geographic specificity of the distribution of the genus Listeria.

In relation to the Brazilian studies, these difficulties are accentuated by the existence of typical Brazilian products, like Minas cheese, sour cheese and butter, among others. However, what can be observed in the literature is the predominance of a low incidence of this microorganism, an agreement found in the majority of the results obtained so far.

Despite the ubiquitous nature of the Listeria genus, the presence of Listeria monocytogenes in cheese is a public health concern. L. monocytogenes is a pathogenic bacterium in humans. It can cause listeriose, which is characterized by fever, muscle ache and gastrointestinal symptoms, such as 
nausea or diarrhea. The infection can affect the nervous system, causing headache, confusion, loss of balance or even convulsion. Healthy people are occasionally infected with $L$. monocytogenes, but rarely present serious symptoms. Risk groups consist of elderly people and immunocompromised (transplant patients and those with lymphoma and AIDS). In addition, the contamination in pregnant women, which presents only mild symptoms (like a common cold), can result in the infection of the embryo, leading to spontaneous abortion, premature birth, severe infections of the new-born or stillbirth (Bille et al., 1999). Even though L. innocua is not pathogenic to humans, its growth in cheese samples suggests the possibility of the growth of L. monocytogenes in these products, representing a potencional risk to consumers.

The importance of this work from the public health view point is that it shows that a potential risk to the health of the general population, heightened by the increase in the number of elderly and the immunodepressed for whom $L$. monocytogenes is potentially serious and also by the fact that $L$. monocytogenes isolates which belong to serotype 1/ 2a were found among those extracted. Furthermore, this is one of the three serotypes most commonly responsible for outbreaks of listeriosis $(1 / 2 \mathrm{a}, 1 / 2 \mathrm{~b}$, the most frequent being 4 b) (Kerouanton et al., 1998; Margolles et al., 1998; Hofer et al., 2000).

The results of isolate serotyping ( $1 / 2 \mathrm{a}$ for $L$. monocytogenes and 6a for L. innocua) are in agreement with isolates found in milk-based products according to Hofer et al. (2000).

The presence of Listeria monocytogenes in the cheeses analyzed, points to the occurrence of failures in the cheese production process by some producers in the State of Paraná. The presence of other Listeria spp. species indicates that the production process may also permit contamination by L. monocytogenes, thus serving as an alert for a critical review of the process, to avoid contamination in critical points of the production process.

The absence of Listeria monocytogenes in the ice cream samples analyzed is supported by the fact that all the companies surveyed use UHT milk as a raw material for ice cream production. This result suggests that the work developed by the Sanitary Vigilance Agency of Paraná State is succeeding in the sense of providing guidance for the producers in the Good Fabrication Practices of 2002.

\section{CONCLUSION}

Results show that the presence of Listeria spp. was not detected by the VIP ${ }^{\mathrm{R}}$ Biocontrol method in ice cream samples from the Curitiba region. In relation to the cheese samples sold in different regions of the State of Paraná, $6.70 \%$ of them were inappropriate for consumption, according to the legal standard, because Listeria monocytogenes was present. In the other cheese samples, the isolation of Listeria innocua $(5.50 \%)$ were also observed.

The existence of flaws in the production process of cheese produced in the State of Paraná is indicated by the occurrence of positive samples for L. monocytogenes. This illustrates the need for handling improvement during the collection and transportation of the raw material, and the processing of the cheese.

The results of the work show the viability of the use of the VIP method by the product's producers, thus, helping to reduce the risk of contaminated products reaching the consumer.

Effective action from the sanitary vigilance agency is required to preserve consumer health, due to the severity of hazardous infection which this microorganism can cause, especially to populations at risk.

\section{RESUMO}

\section{Ocorrência de Listeria monocytogenes em queijos e sorvetes produzidos no Estado do Paraná, Brasil}

A ocorrência de Listeria monocytogenes em sorvetes e alguns tipos de queijos macios e semi-macios produzidos e vendidos no Estado do Paraná Brasil foram avaliados. Noventa amostras de queijo e sessenta amostras de sorvete foram analisadas seguindo os protocolos da AOAC e FDA. Nas amostras de sorvete, não ocorreu o isolamento de Listeria spp. Foi detectada Listeria spp em 12,20\% de amostras de queijo, das quais 6 (6,70\%) foram positivas para Listeria monocytogenes. Foi também observada a presença de Listeria innocua em 5 amostras $(5,50 \%)$ das mesmas amostras. Pelos resultados deste trabalho pode-se pressupor que existe um risco potencial à saúde da população brasileira com o agravante ainda, desta estar envelhecendo e aumentando o número de imunodeprimidos. Os resultados indicam a necessidade de implementação do monitoramento deste microrganismo pelos produtores bem como pela fiscalização. Mostra também que o método VIP é um método viável na triagem de amostras contaminadas para a liberação do produto para a comercialização por ser rápido, confiável e não requerer equipamentos adicionais.

UNITERMOS: Listeria monocytogenes/ocorrência. Queijo/análise microbiológica. Sorvete/análise microbiológica.

\section{ACKNOWLEDGMENTS}

We would like to thank the Secretaria de Estado da 
Saúde do Paraná, Vigilância Sanitária and Laboratório Central do Estado do Paraná, for their valuable assistance in collecting the samples, as well as for the donation of the facilities and the sponsorship for the performance of the essays. Thanks also to the Adolfo Lutz Institute for the complementary biochemical assays, Institute Oswaldo Cruz for serological assays of the isolated strains, and to Fundação Araucária for sponsoring part of the project.

\section{REFERENCES}

AZADIAN, B.S.; FINNERTY, G.T.; PEARSON, A.D. Cheese-borne Listeria meningitis in immunocompetent patient. Lancet, Boston, v.1, n.8633, p.322-323, 1989.

BECKERS, H.J.; SOENTORO, P.S.S.; DELFGOU-VAN ASH, E.H.H. The occurence of Listeria monocytogenes in soft cheeses and raw milk and its resistence to, heat. Int. J. Food Microbiol., Amsterdam, v.4, n.3, p.249-256, 1987.

BILLE, J.; ROCOURT, J.; SWAMINATHAN, B. Listeria, Erysipelthix and Kurthia. In: MURRAY,P.R.; BARON, E.J. (Eds.). Manual of clinical microbiology. 7.ed. Washington: American Society for Microbiology, 1999. p.346-356.

BIOCONTROL SYSTEMS.AOAC Official Method 997.03 Bellevue, WA 98005, 1997.

BORGES, M.F.; FEITOSA, T.; NASSU, R.T.; MUNIZ, C.R.; AZEVEDO, E.H.F.; FIGUEIREDO, E.A.T. Microrganismos patogênicos e indicadores em queijo de coalho produzido no estado do Ceará, Brasil. Bol. Cent. Pesqui. Process. Aliment., Curitiba, v.21, n.1, p.31-40, 2003.

BRANCO, M.A.A.C; FIGUEIREDO, E.A.T.; BORGES, M.F.; SILVA, M.C.D; DESTRO, M.T. Incidência de Listeria monocytogenes em queijo de coalho refrigerado produzido industrialmente. Bol. Cent. Pesqui. Process. Aliment., Curitiba, v.21, n.2, p.393-408, 2003.

BRASIL. Ministério da Saúde. Agência Nacional de Vigilância Sanitária. Resolução RDC n.12, de 2 de janeiro de 2001. Aprova o regulamento técnico de princípios gerais para o estabelecimento de critérios e padrões microbiológicos para alimentos e seus anexos. Diário Oficial [da] República Federativa do Brasil, Brasília, 10 jan. Seção 1, 2001.
BRASIL. Ministério da Saúde. Agência Nacional de Vigilância Sanitária. Programa nacional de monitoramento da qualidade de produtos dispensados de registro. Brasília, 2002.

CASAROTTI, V.; GALLO, C.R.; CAMARGO, R. Ocorrência de Listeria monocytogenes em leite cru, leite pasteurizado tipo $\mathrm{C}$ e queijo minas frescal comercializados em Piracicaba-SP. Arch. Latinoam. Nutr., Caracas, v.44, n.3, 1994.

COLAK, H.; HAMPIKYAN, H.; BINGOL, E.B.; ULUSOY. Prevalence of L. monocytogenes and Salmonella spp. in Tulum cheese. Food Control, London, v.18, p.576-579, 2007.

CORDANO, A.M.; ROCOURT, J. Occurrence of Listeria monocytogenes in food in Chile. Int. J. Food Microbiol., Amsterdam, v.70, p.175-178, 2001.

DESTRO, M.T.; SERRANO, A.M.; KABUKI, D.Y. Isolation of Listeria species from some Brazilian meat and dairy products. Food Control, London, v.2, n.2, p.110$112,1991$.

FARBER, J.M.; JOHNSTON, M.A.; PURVIS, U.; LOITT, A. Surveillance of soft and semi-soft cheeses for the presence of Listeria spp. Int. J. Food Microbiol., Amsterdam, v.5, n.2, p.157-163, 1987.

FDA. FOOD AND DRUG ADMINISTRATION. Bacteriological analytical manual. 8.ed. Gaithersburg, 1995. $562 \mathrm{p}$.

FEITOSA, T.; BORGES, M.F.; NASSU, R.T.; AZEVEDO, E.H.F.; MUNIZ, C.R. Salmonella sp., Listeria sp. and hygienic sanitary indicator microorganisms in cheeses from Rio Grande do Norte State. Ciênc. Tecnol. Aliment., Campinas, v.23, p.162-165, 2003.

GUERRA, M.M.; MCLAUCHLIN, J.; BERNARDO, F.A. Listeria in ready-to-eat and unprocessed foods produced in Portugal. Food Microbiol., London, v.18, n.4, p.423429, 2001.

HO, J.L.; SHANDS, K.N.; FRIEDLAND, G.; ECKIND, P.; FRASER, D.W. An outbreak of type 4 b Listeria monocytogenes infection involving patients from eight Boston hospitals. Arch. Intern. Med., Chicago, v.146, p.520-524, 1986. 
HOFER, E.; RIBEIRO, R.; FEITOSA, D.P. Species and serovars of the genus Listeria isolated from different sources in Brazil from 1971 to 1997. Mem. Inst. Oswaldo Cruz, Rio de Janeiro, v.95, p.615-620, 2000.

KEROUANTON, A.; BRISABOIS, A.; DENOYER, E.; DILASSER, F.; GROUT, J.; SALVAT, G.; PICARD, B. Comparrison of five typing methods for the epidemiological study of Listeria monocytogenes. Int. J. Food Microbiol., Amsterdam, v.43, p.61-71, 1998.

LOW, J.C.; DONACHIE, W. A review of Listeria monocytogenes and listeriosis. Vet. J., Amsterdam, v.153, p.9-29, 1997.

MANFREDA, G.; CESARE de A.; STELLA, S.; COZZI, M.; CANTONI, C. Occurrence and ribotypes of Listeria monocytogenes in Gorgonzola cheeses. Int. J. Food Microbiol., Amsterdam, v.102, p.287-293, 2005.

MARGOLLES, A.; MAYO, B.; REYES-GAVILÁN, C.G. Polymorphism of Listeria monocytogenes and Listeria innocua strains isolated from short-ripened cheeses. $J$. Appl. Microbiol., Bedford, v.84, p.255-262, 1998.

McLAUCHLIN, J. The pathogenicity of Listeria monocytogenes: a public health perspective. Rev. Med. Microbiol., Glasgow, v.8, p.1-14, 1997.

OLIVEIRA, A.N. Bactérias do gênero Listeria em leite e derivados no comércio varejista de Goiânia-Goiás. Belo Horizonte, 1993. 101p. [Dissertação Mestrado. Escola de Veterinária. Universidade Federal de Minas Gerais].

PINI, P.N.; GILBERT, R.J. A comparison of two procedures for the isolation of Listeria monocytogenes from raw chicklens and soft cheeses. Int. J. Food Microbiol., Amsterdam, v.7, n.4, p.331-337, 1988

PINTADO, C.M.B.S.; OLIVEIRA, A.; PAMPULHA, M.E.; FERREIRA, M.A.S.S. Prevalence and characterization of Listeria monocytogenes isolated from soft cheese. Food Microbiol., London, v.22, p.79-85, 2005.

RAMOS, S.N.M.; COSTA, C. A ocorrência de Listeria monocytogenes em queijo artesanal tipo coalho comercializado na cidade de Manaus- AM, Brasil. Acta Amazônica, Manaus, v.33, n.4, p.613-618, 2003.
RORVICK, L.M.; YNDESTAD, M. Listeria monocytogenes in foods in Norway. Int. J. Food Microbiol., Amsterdam, v.13, n.2, p. 97-104, June, 1991.

RYSER, E.T.; MARTH, E.H. Occurrence of Listeria in foods: milk and dairy foods. In: MILLER, A.J.; SMITH, J.L.; SOMKUTI, G.A.(Eds.) Topics in industrial microbiology: foodborne listeriosis. London: Elsevier, 1990. cap.23, p.151-163.

SCHUCHAT, A.; SWAMINATHAN, B.; BROOME, C.V. Epidemiology of humam listerioses. Clin. Microbiol. Rev., Washington, v.4, p.169-183, 1991.

SCHWAB, J.P. Listeria monocytogenes em queijo colonial artesanal comercializado em Porto Alegre. Porto Alegre, 1994. 101p. [Dissertação de Mestrado. Agronomia. Universidade Federal do Rio Grande do Sul].

SILVA, I.M.M.; ALMEIDA, R.C.C.; ALVES, M.A.O.; ALMEIDA, P.F. Occurrence of Listeria spp. in critical control points and the environment of Minas Frescal cheese processing. Int. J. Food Microbiol., Amsterdam, v.81, p.241-248, 2003.

SILVA, M.C.D.; HOFER, E.; TIBANA,A. Incidence of Listeria monocytogenes in cheese produced in Rio de Janeiro, Brazil. J. Food Prot., Des Moines, v.61, n.3, p.354-356, 1998.

SOUZA, R.A. Incidencia de L. monocytogenes em queijo tipo coalho artesanal comercializado à temperatura ambiente em Fortaleza - CE. Fortaleza, 2002. 78p. [Dissertação de Mestrado. Departamento de Tecnologia de Alimentos. Universidade Federal do Ceará].

TERPLAN, G.; SCHOEN, R.; SPRINGMEYER, W. et al. Vorkommen, verhaletn und bedeutung von Listeria in milch und michprodukten. Arch. Lebensmittelhyg., Hannover, v.37, n.6, p.131-137, 1986.

WARBURTON, D.W.; BOVILLE, A. Detection of Listeria spp. in foods and environmental samples by the VIP method. In: The Compedium of Analytical Methods, v.2, 2003. Disponível em: $<$ http://www.hs-sc.gc.ca/food-aliment>. Acesso em: 10 jan. 2004. 
WEBER, A; BAUMANN, C.; POTEL, J.; FRIESS, H. Incidence of Listeria monocytogenes and Listeria innocua in cheese. (Nachweis von Listeria monocytogenes und Listeria innocua in Käse). Berl. Münch. Tierarztl. Wschr., v.101, p.373-375, 1988.

WINDRANTZ, P.; ARIAS, M.L. Evaluation of the bacteriological quality of ice cream sold at San Jose, Costa Rica. Arch. Latinoamer. Nutric., Caracas, v.50, n.3, p.301-303, 2000.
WONG, H.C.; CHAO, W.L.; LEE, S.J. Incidence and characterization of $L$. monocytogenes in foods available in Taiwan. Appl. Environ. Microbiol., Washington, v.56, p.3101-3104, 1990.

Recebido para publicação em 15 de agosto de 2007 Aceito para publicação em 13 de dezembro de 2007 